\title{
THE VALUE OF THE NEW BUSINESSES FROM THE DIGITAL ECONOMY: CASE STUDY FROM E-COMMERCE
}

\author{
Mădălina Viorica MANU \\ The Bucharest University of Economic Studies, Bucharest, Romania \\ mvmadalina@yahoo.com \\ Ilie VASILE \\ The Bucharest University of Economic Studies, Bucharest, Romania \\ vasile.lie@fin.ase.ro
}

\begin{abstract}
This paper aims to challenge the conventional wisdom in finance by studying the success factors of the development of unicorn companies as the most successful and fastest-growing start-ups/ established firms. Romania is now on the map of the International Unicorn Club, with two young Unicorns in technology, since 2018. The purpose of the paper is to analyze mergers and acquisitions and companies valued more than $\$ 1 \mathrm{~B}$. The research questions to be answered are: What is the value of control in mergers and acquisitions? Why the initial estimates of a company's value can be very wrong?

The market approach in this research allows the readers understand the context of the phenomena analyzed and the information on comparable transactions.

The work to be discussed in the paper is the importance of choosing one valuable objective of the company, in the context of the theory of the value maximization as the single important objective of a company.

The model of enterprise value for listed companies should encompass a market variable, such as the value of financing a sector gets and the ownership (control) variable.
\end{abstract}

Keywords: value, revenue, target, e-commerce, unicorn, M\&A, EBITDA.

\section{INTRODUCTION}

Start-ups and established firms manage to evolve rapidly either independently or within an international large and successful group and, in this paper, the authors aim to find out how such companies succeed. In the actual economy, many Romanian companies fight hard to find their way to success (or survival), in the absence of one valuable objective of the business. This article is a minor extension of the authors research ['] on the enterprise value (EV) and its determinants, in order to understand the ways to increase it or maximize the company value, while considering the theory of value maximization as the single important objective of a company. 
We aim to demonstrate the practical importance of this principle in the life of a company. The analysis starts with a company [i] with a mission to build a service that the customers would love (Naspers, 2019a); eMag was a small e-commerce company with a monthly revenue of less than 2 million euro, in 2009 , but with a dream to cross borders and offer a platform where people could buy anything and now the company is the largest retailer online in Romania [ii]] and has become part of the Naspers group [iv], since October 2012. This company became profitable in the second half of 2018 and a major driver of the revenue improvement, delivered a solid performance, with gross merchandise value (GMV) growth, improved profitability boosted by increased gross profit margins and cost control (Naspers, 2018). In 2018, the Romanian e-commerce company eMag has become the $2^{\text {nd }}$ Unicorn in Romania, after UiPath [v].

The objective of the first Romanian unicorn UiPath (2018b), to enhance customer experience, seems to be very good, if we judge by their results [vi]. UiPath raised more than $\$ 400$ million from tier one investors (Series A in April 2017 with 200 customers at a valuation of $\$ 140$ million, then another $\$ 153$ million in March 2018 at a valuation of $\$ 1.1$ billion); closed in November 2018, UiPath's Series C financing totals $\$ 265$ million at a valuation of $\$ 3$ billion (UiPath, 2019b). Created to drive company's vision for an automated and fully-employed world, the UiPath Academic Alliance (2018a) represents UiPath's ambition to serve more than one million students and one thousand schools in the next three years.

This paper analyses mergers and acquisitions and companies valued more than $\$ 1 \mathrm{~B}$, in order to challenge the conventional wisdom in finance by studying the development of unicorn [vii] companies as the most successful and fastest-growing start-ups (Butuzova, 2018). For instance, Naspers (2019b) grew by investing in, acquiring and building leading companies with sustainable competitive advantages, throughout its 100-year history, and continues to back new business models to fuel growth.

\section{PROBLEM STATEMENT}

This paper starts from professor Jensen's theory (2002) that it is impossible to maximize in more than one dimension, and the criterion for deciding when implementing organizational change should be the increase in the long-term market value of the firm (Jensen, 2002).

When analyzing successful companies' objectives, we come to agree that Romanian companies find success when they focus on a single value driven objective for the long term and that difficulties rise when companies waste their efforts and limited resources on too many (unsustainable) objectives for the short term. The company's strategy is, therefore, of utmost importance. 
In the analysis of successful Romanian IT companies, we try to identify the key success factors to be measured in order to be able to model the enterprise value (EV). Also, many (large) companies acquire others in order to add value to their products through diversification, for synergies or control. So, what is the value of control in mergers and acquisitions? Why the initial estimates of a company's value can be very wrong?

\section{LITERATURE REVIEW}

When implementing organizational change, the aim should be the increase in the long-term market value of the firm (MV), which is 'the sum of the values of all financial claims on the firm, including equity, debt, preferred stock, and warrants' (Jensen, 2002). Wruck et al. (1991) gave example of a small nonprofit firm that almost destroyed itself while trying to maximize over a dozen dimensions at the same time; Cools and Praag (2000) were the first to formally test the proposition that multiple objectives handicap firms using 80 Dutch firms in the 1993-1997 period, then concluded: "Our findings show the importance of setting one single target for value creation" (Jensen, 2002).

The e-commerce and cloud-storage giant Amazon isn't just secretive, the way Apple is, but values surprise. Communication with stakeholders should be a basis for creating enterprise value, e.g. clients or co-developers of innovative basic processes. Improving/ modernizing methods/tools of communication with stakeholders is usually a cost for the surveyed enterprises than the source of development, e.g. in the long run (Wereda and Woźniak, 2018).

Advances in technology have improved access to real-time market information and business analytics, improving communication and the integrated management of their operations; improved telecommunications, information management software and personal computing decreased significantly firm' costs, enabling the creation of efficient business models. Although digital services can substantially expand the reach of businesses, they require massive investments in infrastructure and also, skills (OECD, 2015).

"Disruptive innovation" describes how new entrants target the bottom of a market and then relentlessly move up, ousting established providers by successfully targeting those overlooked segments, frequently at a lower price (Christensen, 2018). For example, companies such as Amazon disrupted entire industries. Innovations, new technologies or business models reshape industries.

The 'big data', defined by OECD (2015) as datasets large enough that they cannot be managed or analysed using typical database management tools, is now a must have. Data analytics, defined as the use of data storage and process techniques to support decisions are becoming a driver for innovation in 
a number of scientific areas and are used in collaborative and crowd-based projects. Cloud computing increased data storage and processing capacity.

Small and medium-sized enterprises (SMEs), and governments have access now to supercomputing resources. (OECD, 2013)

Automation changes the activities of all sectors, including finance, as robots and computers can perform routine physical work, being increasingly capable of accomplishing activities that include cognitive capabilities. The analysis of the impact of automation, covering $78 \%$ of the global labor market, the high percentage of time spent on activities with the technical potential for automation by adapting currently demonstrated technology shows a very high potential for automation, in many countries. In figure 1, we can see the high potential for automation [viii], for the Finance and insurance sector (McKinsey Global Institute, 2018).

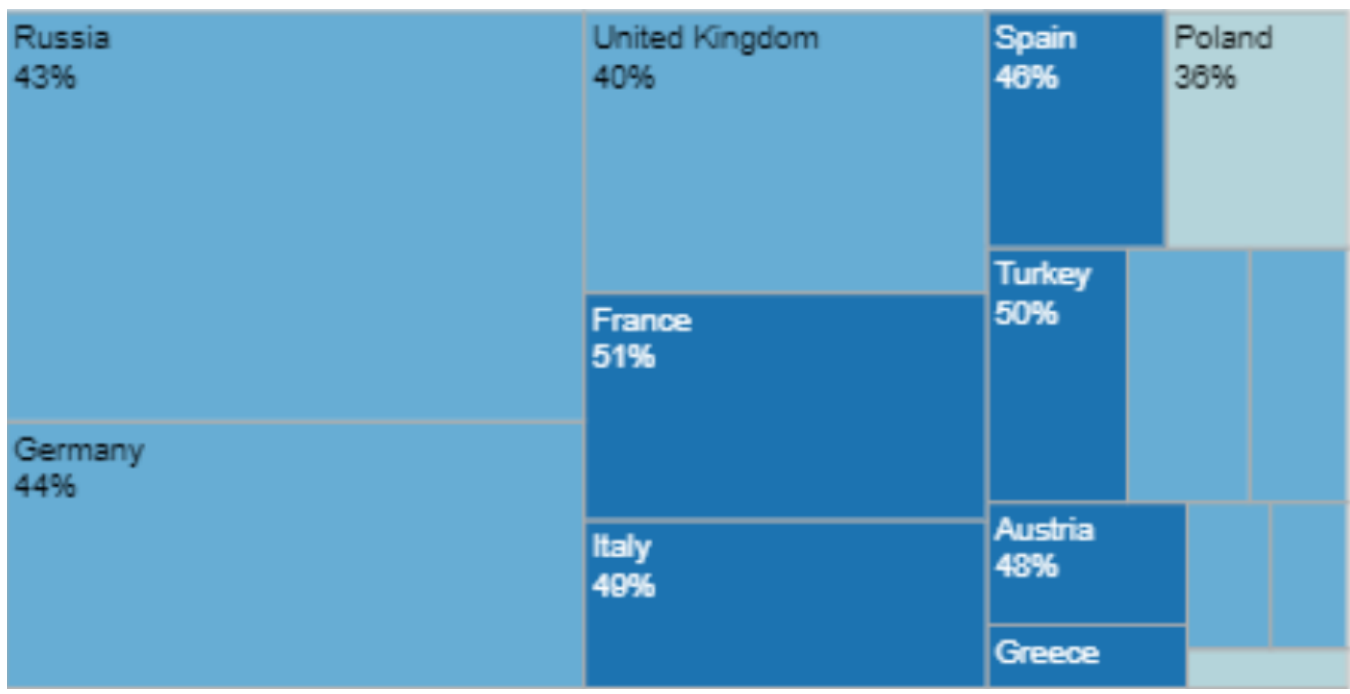

FIGURE 1. THE HIGH POTENTIAL FOR AUTOMATION IN THE FINANCE AND INSURANCE SECTOR

Source: McKinsey Global Institute, 2018

In another top, the largest companies, in 2008, were oil and gas producers, while in 2018, the top 10 companies in the world were technology companies mainly (Johnston, 2018). The technology giants (such as Apple, Google and Facebook) have achieved world domination (figure 2) by investing heavily in developing new products and services leading to an explosion in innovation and faster growth and disrupting established companies The only company remaining in the global top 10 since 2008 is Microsoft, founded in 1975, which doubled its value.

Another giant, founded in 1998 by Stanford Ph.D. student, with funding of $\$ 41.00 \mathrm{M}$ and valuation of $\$ 777.96 \mathrm{~B}$, Google's search technologies now connect millions of people with information; similar companies (figure 2) are Facebook (\$2.53B) and Amazon (\$16.98M). (CBINSIGHTS, 2019) 


\begin{tabular}{|c|c|c|c|c|c|c|c|}
\hline \multicolumn{4}{|c|}{2018} & \multicolumn{4}{|c|}{2008} \\
\hline Rank & Company & Founded & USbn & Rank & Company & Founded & USbn \\
\hline 1. & Apple & 1976 & 890 & 1. & PetroChina & 1999 & 728 \\
\hline 2. & Google & 1998 & 768 & 2. & Exxon & 1870 & 492 \\
\hline 3. & Microsoft & 1975 & 680 & 3. & General Electric & 1892 & 358 \\
\hline 4. & Amazon & 1994 & 592 & 4. & China Mobile & 1997 & 344 \\
\hline 5. & Facebook & 2004 & 545 & 5. & ICBC (China) & 1984 & 336 \\
\hline 6. & Tencent (China) & 1998 & 526 & 6. & Gazprom(Russia) & 1989 & 332 \\
\hline 7. & Berkshire & 1955 & 496 & 7. & Microsoft & 1975 & 313 \\
\hline 8. & Alibaba (China) & 1999 & 488 & 8. & Royal Dutch Shell & 1907 & 266 \\
\hline 9. & $J \& J$ & 1886 & 380 & 9. & Sinopec (China) & 2000 & 257 \\
\hline 10. & $\begin{array}{c}\text { JP Morgan } \\
\text { e: Bloomberg, Google }\end{array}$ & 1871 & 375 & 10. & AT\&T & 1885 & $\begin{array}{l}238 \\
\text { Accesat: }\end{array}$ \\
\hline
\end{tabular}

FIGURE 2. THE LARGEST COMPANIES IN 2008 VS. THE YEAR 2018

Source: Johnston, 2018

On the other side, the founders of the companies with little to no credit history (known as a "thin file company") do not get good pricing or credit terms (being considered risky or "near bankruptcy" - even though the revenue and bank balance clearly show otherwise) and hundreds of thousands of private SMEs and startups see similar challenges. For private companies, these challenges decrease profits and productivity (CBInsights, 2015). Investors look at startups which have not been incorporated yet but still have a big potential for growth (Butuzova, 2018).

When the seller sees that the company is not worth as much as they thought it was should take steps to increase its value. When an e-commerce company, eBay, bought, in 2005, Skype - a small, marginally profitable communications company, for $\$ 3.1$ billion, the company was worth only $\$ 1.7$ billion and eBay took a $\$ 1.4$ billion charge against profits to account for the difference. Then, in 2010 , eBay sold $70 \%$ of Skype to a group of investors (including the original founders) for $\$ 1.9$ billion (making Skype worth about $\$ 2.7$ billion); in 2011, Microsoft bought Skype for $\$ 8.5$ billion, even though Skype was still at loss. (Knight, 2016)

High-tech and innovative unicorns are drivers of development and their high capitalization is indeed justified. The potential and growth opportunities of such companies are the main drivers of their overestimated value. The Unicorn Club is a group of billion-dollar startups with a revolutionary trade brand tagged to their business operations (figure 3) comprises companies under E-commerce sector $(17 \%)$, Internet Software and Services (14\%) and Financial technology $(11 \%)$. 


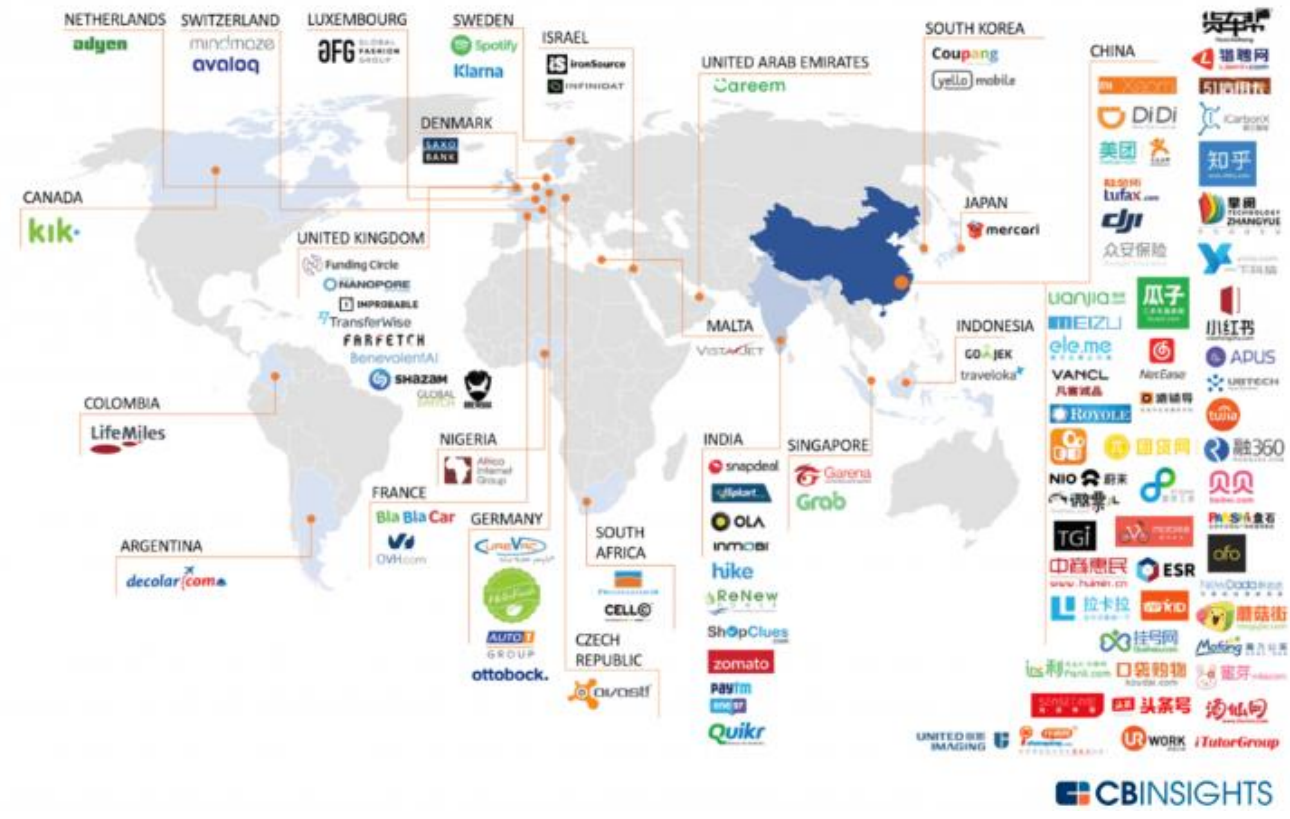

FIGURE 3. THE INTERNATIONAL UNICORN CLUB AS IN SEPTEMBER 2017

Source: Johnston, 2018

In 2015, 24 Unicorns (out of 50 predicted) have hit that mark (48\%) by being acquired for $\$ 1 \mathrm{~B}+(4$ companies), or gone public, and 14 went on to raise additional equity funding totaling $\$ 1.4 \mathrm{~B}$ (of the 26 non-unicorns); an algorithm [ix] to identify unicorns was developed as an evidence-based, statistical approach to assess private company health. The Money ball approach, a statistical analysis for predictions, is not new in other domains, but it was to the private markets and CBInsights (2015) built it using machine-learning and data science. This approach comprised of 3 individual models shown below.

1. The market model looks at the number of companies in an industry, the financing and exit momentum and the overall quality and quantity of investors participating in that industry.

For example, in a study on the impact of the artificial intelligence (Al), McKinsey Global Institute (2018) classified the companies as:

(i) front-runners (companies that fully absorb Al tools across their enterprises over the next five to seven years);

By 2030, the front-runners could potentially double their cash flow - the economic benefit captured minus associated investment and transition costs, at an additional annual net cash-flow growth of about $6 \%$. 
(ii) Non-adopters (companies that do not adopt Al technologies) and might experience around a $20 \%$ decline in their cash flow due to the market share shift from laggards to frontrunners.

2. Money - the burn rate, the quality of the investors and syndicate that may be part of the company, its financing position relative to industry peers \& competitors, etc. What is the financial health of the company?

3. Momentum - how much traction does the company have?

Most attempts to quantify tech company health have almost exclusively focused on momentum, which is necessary but not sufficient.

Digital transformation remains top of the agenda as companies use M\&A to add innovative capabilities, improve customer engagement and stays relevant in a changing market; renewables and network assets remain the most attractive acquisition targets and digitization can influence transaction strategies in developed countries. $48 \%$ of the executives surveyed cite digital innovation, the search for growth and sector convergence as the most prominent topics on their agenda (Rennie, 2017). Investors including big corporates have plowed that much into promising holding companies. In Emerging Europe, the overall deal value increased and deal volume remained virtually flat in 2018, even if the labor costs keep the region competitive and internet millionaires have become angel investors for tech start-ups, in such areas as gaming, Artificial intelligence technology, anti-virus software and search and compare platforms based on complex algorithms (CMS, 2017; Antonescu, 2018).

\section{METHOD}

Companies with different capital structures can be compared by the Enterprise Value (EV) - a firm valuation proxy.

EV approximates current market value (MV) of a company to determine takeover or merger price of a firm; unlike Market Cap, EV takes into account: the entire liquid asset, outstanding debt, and exotic equity instruments (from the balance sheet). When takeover occurs, the parent company will have to assume the target company's liabilities but will take possession of all cash and cash equivalents.

The value of control should be inversely proportional to the perceived quality of that management and its capacity to maximize firm value, so the value of control will be much greater for a poorly managed firm that operates at below optimum capacity than it is for a well-managed firm (table 1). 
TABLE 1. MOTIVES BEHIND ACQUISITIONS AND FIRM VALUE

\begin{tabular}{|l|l|l|}
\hline Acquisition motive & Value target firm as & Examples \\
\hline $\begin{array}{l}\text { Diversification, for } \\
\text { stabilizing earnings and } \\
\text { reducing risk }\end{array}$ & Status Quo Valuation: no extra premium & $\begin{array}{l}\text { Naspers bought } \\
\text { eMag; } \\
\text { Skype }\end{array}$ \\
\hline $\begin{array}{l}\text { Operating Synergy } \\
\text {-Cost Savings: in same } \\
\text { business to create } \\
\text { economies of scale; } \\
\text {-Higher growth }\end{array}$ & $\begin{array}{l}\text { Target Firm Value = Independent Value + Synergy } \\
\text { Synergy = value of the bidding firm (pre-acquisition) - value } \\
\text { of the target firm (with control premium) }\end{array}$ & $\begin{array}{l}\text { Ilva S.p.A. [x]; } \\
\text { Emag (in 2012) }\end{array}$ \\
\hline Financial Synergy, from: & $\begin{array}{l}\text { Tax Benefits: Value of Target Firm + PV of Tax Benefits } \\
\text { Increased Debt Capacity: Value of Target Firm + Increase } \\
\text { in Value from Debt } \\
\text { Cash Slack: Value of Target Firm + NPV of Projects/ Target }\end{array}$ & UiPath \\
\hline $\begin{array}{l}\text { Control (of poorly managed } \\
\text { firms) }\end{array}$ & $\begin{array}{l}\text { Value of Target Firm run optimally (industry averages) } \\
\text { Value of Control = Value of firm, with restructuring - Value } \\
\text { of firm, without restructuring }\end{array}$ & $\begin{array}{l}\text { Skype; } \\
\text { ArcelorMittal } \\
\text { Galați [10] }\end{array}$ \\
\hline
\end{tabular}

Source: adapted from (Damodaran, n.d.)

The control characteristics of the comparable and the subject asset, and also the ownership characteristics (e.g., legal form of ownership, amount percentage held) are common differences that could warrant adjustments. In the market approach, adjustments (discounts or premiums) for differences between the asset and the guideline transactions or publicly-traded securities are:

(i) Control Premiums (Market Participant Acquisition Premiums or MPAPs) and

(ii) Discounts for Lack of Control (DLOC) - differences between the comparable and the subject asset as a result of exercising control. (IVSC, 2017a)

Control Premiums and DLOCs are typically calculated based on an analysis of the specific cash flow enhancements or reductions in risk associated with control or by comparing observed prices paid for controlling interests in publicly-traded securities to the publicly-traded price.

Circumstances where Control Premiums and DLOC should be considered include where:

1. Shares of public companies generally do not have the ability to make decisions related to the operations of the company (they lack control).

When applying the guideline public comparable method to value a subject asset that reflects a controlling interest, a control premium may be appropriate.

2. The guideline transactions often reflect transactions of controlling interests. When valuing a subject asset that reflects a minority interest, a DLOC may be appropriate. (IVSC, 2017b)

The pareto chart in figure 4 shows the importance of obtaining the control according to the distribution of the data by the stake obtained. In the case of the companies studied, eMag is controlled by a holding 
Manu, M.V. and Vasile, I.

THE VALUE OF THE NEW BUSINESSES FROM THE DIGITAL ECONOMY: CASE STUDY FROM E-COMMERCE

from the Netherlands, while UiPath is Privately Held (backing) by 15 investors and its financing status is a Venture Capital-Backed. (PitchBook, 2019)

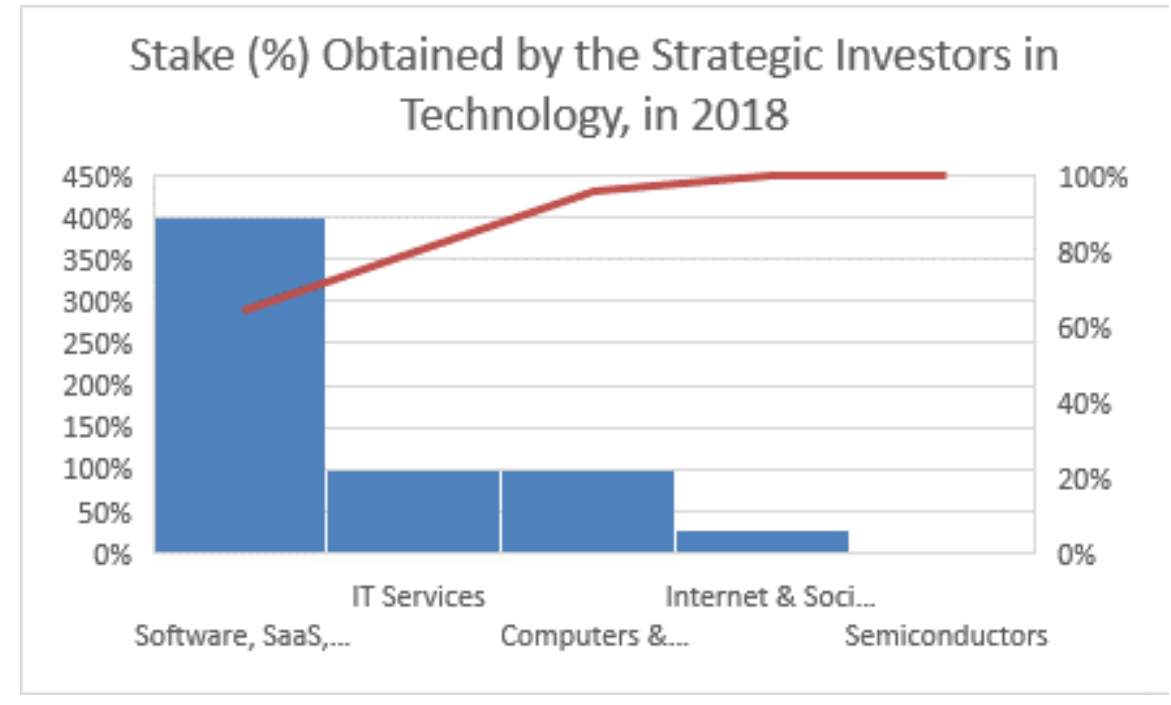

FIGURE 4. A PARETO CHART OF THE DISTRIBUTION OF THE STAKE

Source: author's representation

In a local ranking of Romanian companies dominated by retail companies and auto, the only ecommerce company is the one we study (with bold, in in table 2). According to a country top, this company remained in top 30 and the $2^{\text {nd }}$ IT\&C company in Romania, in 2018, according to its value of 956 mil. Euro (or 4456 mil. Lei in 2018, higher than in 2017), while the first ITC company in the Romanian top 5 is UiPath. (ZF, 2018)

TABLE 2. TOP LOCAL FIRMS BY THEIR ADDRESS AND TURNOVER

\begin{tabular}{|llll|}
\hline Name & $\begin{array}{l}\text { turnover } \\
\text { (mil. Lei) }\end{array}$ & $\begin{array}{l}\text { turnover } \\
\text { (mil. euro) }\end{array}$ & activity \\
AUCHAN ROMÂNIA SA & 5200,00 & 1200,000 & retail \\
MEGA IMAGE SRL & 4900,00 & 1100,000 & $\begin{array}{l}\text { retail } \\
\text { DANTE INTERNATIONAL SA } \\
\text { (known as EMAG) }\end{array}$ \\
RENAULT COMMERCIAL ROUMANIE SRL & 3300,00 & 752,300 & $\begin{array}{l}\text { e-commerce, } \\
\text { ITC }\end{array}$ \\
\hline FARMEXPERT D.C.I. SRL & 3100,00 & 697,300 & auto \\
ELECTROCENTRALE BUCURESTI SA & 3000,00 & 671,500 & pharma \\
& 1700,00 & 395,000 & energy \\
IBM ROMANIA SRL & & & e-commerce, \\
ROUMASPORT SRL & 906,7 & 206,100 & ITC \\
BRICOSTORE ROMANIA SA & 760,6 & 172,900 & retail \\
SIEMENS SRL & 696,1 & 158,200 & DIY \\
\hline
\end{tabular}




\begin{tabular}{|llll|}
\hline C.N."IMPRIMERIA NATIONALA" SA & 434 & 98,600 & Printing \\
JYSK ROMÂNIA SRL & 415,2 & 94,400 & retail \\
AUTO ITALIA IMPEX S.R.L. & 372,4 & 84,600 & auto \\
TRUST MOTORS SRL & 368,8 & 83,800 & auto \\
RODBUN GRUP SRL & 334 & 75,900 & agriculture \\
\hline
\end{tabular}

Source: TopFirme, 2018

According to the data shown above, the ITC sector comprises companies worth 958.4 mil. Euro, which comes second after the retail sector.

Despite the fact the company was not reporting profit, eMag became part of the Naspers group, in October 2012 and became profitable for the first time in the second half of the 2018. Analyzing the firm potential to grow, we look at Naspers (NPSNY) Book Value Per Share [xi] of 12.42X, and the relationship between Net Income and Total Asset, Price to Earnings of 7.15X.

For Naspers, the book value / share category is shown in table 6 . Naspers Limited value of $88.65 \mathrm{~B}$ is $24.41 \%$ lower than that of the Technology sector and significantly higher than that of Internet Content \& Information industry (the value for all stocks is $41.73 \%$ higher than the company).

(WABLE 6. COMPARISON WITH RELATED COMPANIES TRADED ON NEW YORK STOCK EXCHANGE
\begin{tabular}{|l|l|}
\hline Naspers Comparables & Book Value Per Share \\
\hline Naspers (NPSNY) & 12.42 \\
\hline 58 (WUBA) & 22.04 \\
\hline GrubHub (GRUB) & 15.89 \\
\hline Autohome (ATHM) & 12.96 \\
\hline
\end{tabular}

Book Value per Share indicates the level of safety for the common shares after removing effects of liabilities to see how much can sell the stake in the company (at liquidation), as in equation 1:

$$
B V / S=(A-L) / N
$$

where $\mathrm{L}=$ liabilities $\mathrm{A}=$ assets $\mathrm{N}=$ the total number of currently outstanding shares.

\section{RESULTS}

In figure 5, the M\&A activity in Romania has reached a maximum in 2018, while in the CEE area is stagnant. 


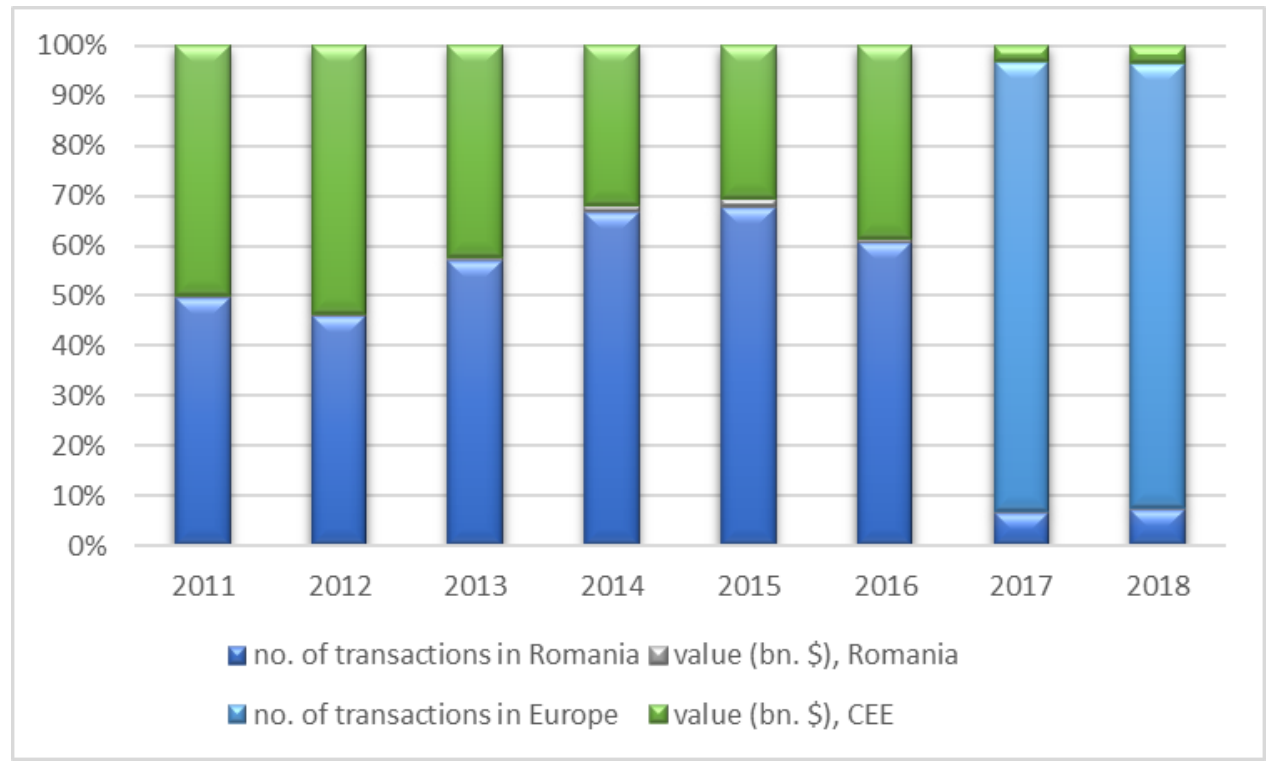

FIGURE 5. M\&A NUMBER OF TRANSACTIONS AND VALUE IN ROMANIA VERSUS EMERGING EUROPE

Source: author's representation, (CMS, 2019)

The large technology companies benefit from globalization, accessing new markets and any promising small company that could compete (figure 5).

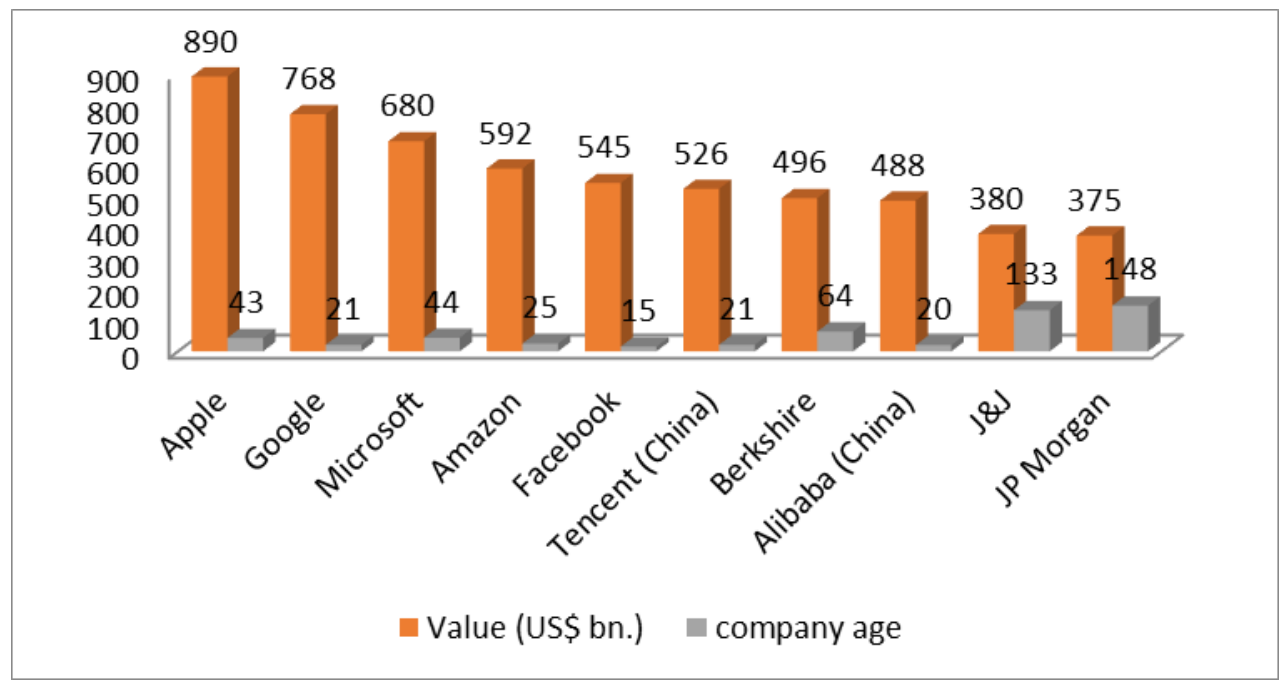

FIGURE 6. THE GLOBAL RISE OF THE ITC COMPANIES IN 2018

Source: authors' representation

The quality of the IT\&C market/ industry the company competes in is critical indeed as it can push along the company. Usually, the managers that act in the same industry or similar industries tend to replicate the success business models of the front-runners. 
Manu, M.V. and Vasile, I.

THE VALUE OF THE NEW BUSINESSES FROM THE DIGITAL ECONOMY: CASE STUDY FROM E-COMMERCE

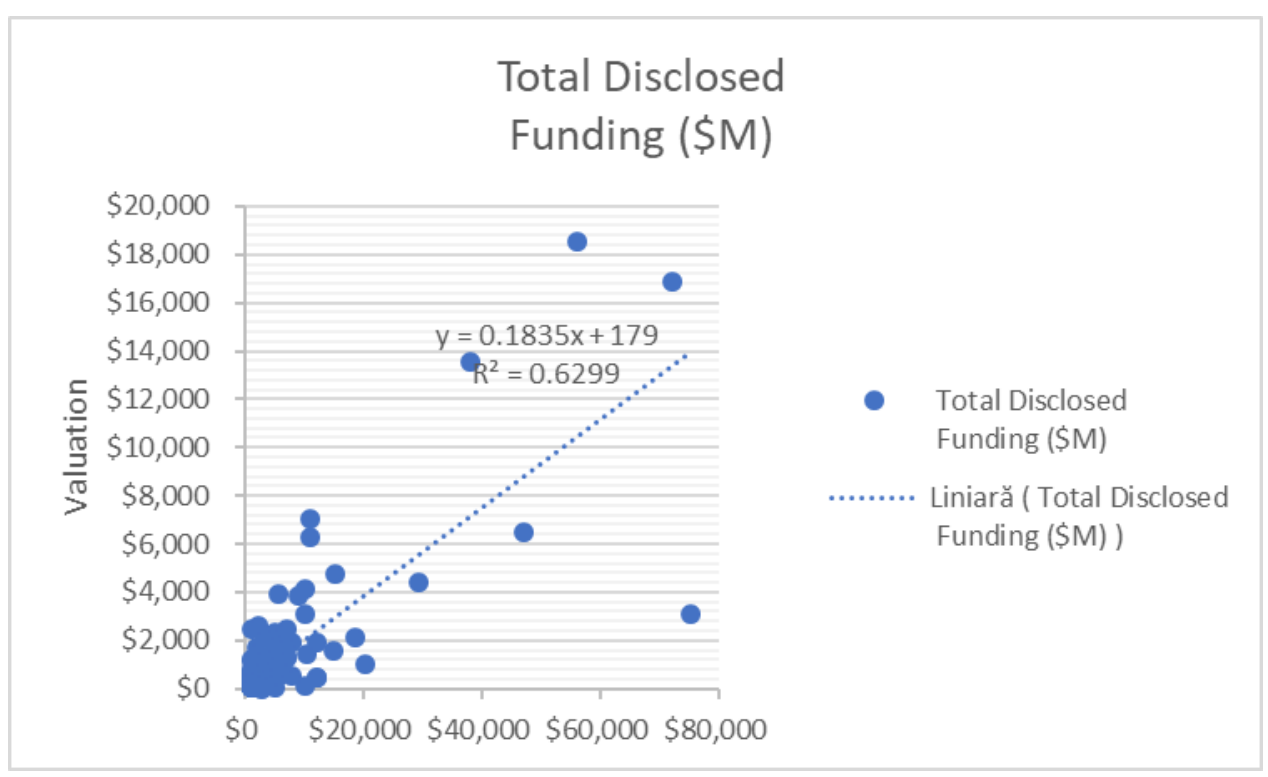

FIGURE 6. SCATTERPLOT OF FUNDING AND VALUATION OF THE UNICORNS

Source: authors' representation

The Pearsons Correlation Coefficient is one of the most common measures of correlation in financial statistics. For the unicorn companies observed [xii], higher valuation was correlated with higher funding (Pearson's $r$ is .79, which is normally considered a large effect) [xii]. In table 5 below, some statistics are included:

TABLE 5 DESCRIPTIVE STATISTICS

\begin{tabular}{|c|c|c|c|}
\hline Valuation (\$M) & & \multicolumn{2}{|c|}{ Total Disclosed Funding (\$M) } \\
\hline Mean & 3576.841935 & Mean & 839.3421569 \\
\hline Standard Error & 443.0011552 & Standard Error & 103.7102973 \\
\hline Median & 1605.5 & Median & 376.75 \\
\hline Mode & 1000 & Mode & 500 \\
\hline Standard Deviation & 7799.840209 & Standard Deviation & 1814.189265 \\
\hline Sample Variance & 60837507.29 & Sample Variance & 3291282.687 \\
\hline Kurtosis & 51.4314886 & Kurtosis & 57.15630799 \\
\hline Skewness & 6.735592687 & Skewness & 6.931031008 \\
\hline Range & 74000 & Range & 18565.9 \\
\hline Minimum & 1000 & Minimum & 1 \\
\hline Maximum & 75000 & Maximum & 18566.9 \\
\hline Sum & 1108821 & Sum & 256838.7 \\
\hline
\end{tabular}


Manu, M.V. and Vasile, I.

THE VALUE OF THE NEW BUSINESSES FROM THE DIGITAL ECONOMY: CASE STUDY FROM E-COMMERCE

\begin{tabular}{|l|l|l|l|}
\hline Count & 310 & Count & 306 \\
\hline
\end{tabular}

Source: authors

\section{CONCLUSIONS AND IMPLICATIONS / DISCUSSIONS}

In the actual economy, many Romanian companies fight hard to find their way to success or survival in the absence of one valuable objective of the business. Managers find ways to transform into Unicorns their small companies or some companies in difficulty, while concentrating on innovation and adding value for the customers.

The founders of the companies with little to no credit history do not get good pricing or credit terms being considered risky or "near bankruptcy" - even though the revenue and bank balance clearly show otherwise; banks and credit card companies give them less or no credit and at worse terms and investors or acquirers are unable to discover them. The owners that identify such problems and also identify pitching opportunities and proper business partners manage to develop their companies.

Companies use M\&A to add innovative capabilities, improve customer engagement and staying relevant in a changing market. Although many owners do not feel very comfortable when giving a stake of their company, there are many ways thy can retain their influence/ control of the company.

The next evolutionary step after knowledge economy might be the network economy, where the knowledge is shared across various networks, to gain economic of scale in a wider scale. "The gradual evolution of network economy would create a well interconnected economic order, which would then begin to concentrate on the passion of individuals, gradually leading to a Passion based economy." (Cluett, 2016)

30 years ago, the World Wide Web was invented by Sir Tim Berners-Lee. The shift to a "knowledge society" and "the rise of knowledge work" previewed by Peter Drucker are now facts. Discontinuities, such as the knowledge technologies, the changes in the world's economy, a society of organizations and the knowledge society changed the structure of the economy (Drucker, 1969).

\section{REFERENCES}

Antonescu, M. (2018). Are Business Leaders Prepared to Handle the Upcoming Revolution in Business Artificial Intelligence?. Quality-Access to Success, 19(166), 15-20.

Benner, K. (2015). The 'Unicorn' Club, Now Admitting New Members. [Online] Available at: https://www.nytimes.com/2015/08/24/technology/the-unicorn-club-now-admitting-newmembers.html?_r=0 (Accessed 02 2019). 
Butuzova, A. (2018). Capitalization of International Unicorn Companies: To What Extent is li Reasonable?. Digest Finance, 23(1), 63-67.

CB Insights. (2018). The Global Unicorn Club. [Online] Available at: https://www.cbinsights.com/research-unicorn-companies (Accessed 03 2019).

CBInsights. (2015). Moneyball For Startups - CB Insights Lands \$1.15M From National Science Foundation and Launches Mosaic To Assess Startup Momentum, Health. [Online] Available at: https://www.cbinsights.com/research/team-blog/mosaic-moneyball-for startups/?utm_source $=\mathrm{CB}+$ Insights+Newsletter\&utm_campaign=6c086afc4b-

TuesNL_02_12_2019\&utm_medium=email\&utm_term=0_9dc0513989-6c086afc4b-92242225 (Accessed 02 2019).

CBInsights. (2019). Understanding Tech Startups' Health. [Online] Available at: https://www.cbinsights.com/marketing/information/Mosaic-Score.pdf?utm_campaign=marketingdownload_mosaic-whitepaper_2019-01\&utm_medium=email\&_hsenc=p2ANqtz9A1JkpK_EWtKVsK9ZIT2z4ZZIx47Ptsoqou8WWPLDaObG00dYBxcFR0vbZiETc05NdyJQgVjuRmH 8fGP8zOorMk_DMlg\&_hsmi= (Accessed 02 2019).

Christensen, C. c. b. L. D. a. R. C. (2018). Business Disruption is here to Stay - What Should Leaders Do?. Quality-Access to Success, 19, p. 35.

Cluett, J. (2016). Research proposal, Network Analysis Can Apply Divination, A Changing Paradigm. [Online] Available at:

file://ID:/Downloads/NetworkAnalysisCanApplyDivinationAChangingParadigmMay2016.pdf (Accessed 01 2019).

CMS. (2017). [Online] Available at: https://cms.law/en/ROU/ (Accessed 2019).

CMS. (2019). Emerging Europe M\&A Report 2018/19, s.I.: s.n.

Cools, K., \& Praag, M. V. (2000). Topsalarissen en aandelenopties. Economisch Statistische Berichten, 85(4240), 69-73.

Damodaran, A. (n.d). Acquisition Valuation. [Online] Available at: http://people.stern.nyu.edu/adamodar/pdfiles/AcqValn.pdf (Accessed 01 2019).

Drucker, P. F. (1969). The Age of Discontinuity. Retrieved December 12, 2019, from https://www.elsevier.com/books/the-age-of-discontinuity/drucker/978-0-434-90395-5.

IVSC. (2017a). Asset Standards - IVS 200 Businesses and Business Interests, London: International Valuation Standards Council.

IVSC. (2017b). General Standards - IVS 105 Valuation Approaches and Methods, London: International Valuation Standards Council. 
Jensen, M. C. (2002). Value Maximization, Stakeholder Theory and the Corporate Objective Function. Business Ethics Quarterly, pp. 235-256.

Johnston, S. (2018). Largest companies 2008 vs. 2018, a lot has changed. [Online] Available at: https://milfordasset.com/insights/largest-companies-2008-vs-2018-lot-changed (Accessed 12 2018).

Knight, J. (2016). Valuation: The EBITDA Multiple Method. HBR Subscriber Exclusive.

Macroaxis LLC. (2019). Naspers Limited. [Online] Available at: https://www.macroaxis.com/invest/ratio/NPSNY--Current-Valuation (Accessed 2019).

McKinsey Global Institute. (2018). Notes from the Al frontier: Modeling the impact of Al on the world economy. [Online] Available at: https://www.mckinsey.com/featured-insights/artificialintelligence/notes-from-the-ai-frontier-modeling-the-impact-of-ai-on-the-world-economy (Accessed 03 2019).

Naspers. (2018). Condensed consolidated interim report for the six months ended 30 September 2018, Cape Town: s.n.

Naspers. (2019a). Strategy. [Online] Available at: https://www.naspers.com/about-us/strategy (Accessed 02 2019).

Naspers. (2019b). What I wish l'd known then. [Online] Available at: https://www.naspers.com/home/news/what-i-wish-i-d-known then?fbclid=IwAR37PesHEpEMM7cGj7Ck2JakdfDa_rWYBMhpYvbPXkf1rV1IsIONRrSTtGY (Accessed 02 2019).

OECD. (2013). [Online] Available at: https://www.oecd-library.org/science-and-technology/exploringdata-driven-innovation-as-a-new-source-of-growth_5k47zw3fcp43-en (Accessed 03 2019).

OECD. (2015). Addressing the Tax Challenges of the Digital Economy, Action 1 - 2015 Final Report. [Online] Available at: https://read.oecd-library.org/taxation/addressing-the-tax-challenges-of-thedigital-economy-action-1-2015-final-report_9789264241046-en\#page70 (Accessed 12 2018).

PitchBook. (2019). Profile Previews. [Online] Available at: https://pitchbook.com/profiles/company/117363-88 (Accessed 2019).

Rennie, M. (2017). M\&A appetite rebounds with renewed economic confidence, EY: s.n.

TopFirme. (2018). Top firme din Sector 6, Bucuresti dupa cifra de afaceri. [Online] Available at: https://www.topfirme.com/judet/bucuresti/localitate/sector\%206/cifra-de-afaceri/ (Accessed 12 2018). UiPath. (2018a). UiPath Launches Academic Alliance to Democratize Automation Education. [Online] Available at: https://www.uipath.com/newsroom/uipath-launches-academic-alliance-to-democratizeautomation-education (Accessed 03 2019). 
UiPath. (2018b). We are UiPath. [Online] Available at: https://www.uipath.com/company/aboutus?ads_adid=67082801428\&ads_cmpid=1535965809\&ads_creative $=295539946928 \&$ ads_matchty pe=b\&ads_network $=g \&$ ads_targetid $=k w d-$

379631421296\&ttv=2\&utm_campaign=UP189BRN\&utm_content=brandbidMS\&utm_medium=ppc\& utm_source=adwords\&ut (Accessed 01 2019).

UiPath. (2019a). Company overview. [Online] Available at: https://www.uipath.com/hubfs/Valentin/Brand\%20Kit/Company\%200verview.pdf (Accessed 02 2019). UiPath. (2019b). Our Investors. [Online] Available at: https://www.uipath.com/company/investors (Accessed 02 2019).

Wereda, W. \& WOŻNIAK, J. (2018). The Way to Organizational Excellence of Innovative Enterprises Through Communication with Stakeholders. Bucharest, Tritonic Publishing House, p. 917.

Wruck, K. H., Jensen, M. C., \& Barry, B. (1991). Fighton, Inc.,(A) and (B) Teaching Note. Harvard Business School Case\# 5-491, 111.

ZF. (2018). Cele mai valoroase 100 de companii din Romania. [Online] Available at: http://edition.pagesuite.com/html5/reader/production/default.aspx?pubname=\&edid=2b6e46fa-32c842ff-bd45-c50b9251b990 (Accessed 03 2019).

i etimm (2018) Current issue. Journal of Emerging Trends in Marketing and Management. http://www.etimm.ase.ro/?p=31

ii DANTE INTERNATIONAL S.A. known by the brand eMag

iii eMAG, founded in 2001, has now extended in Bulgaria and Poland, too.

iv Naspers Limited (NPSNY) is traded on OTC Market in USA and employs 24,482 people. The company currently falls under 'Large-Cap' category with current market capitalization of 98.87B. Naspers Limited classifies itself under Technology sector and is part of Internet Content \& Information industry.

v Created in 2015 on the foundation of the 10-year old Romanian software outsourcing company, UiPath began orienting resources into training and orchestrating software robots back in 2012, and one year later the company initiated its first RPA journeys, with Sutherland and Dell. (UiPath 2019a)

vi In 2018, the company is valued at 2550 mil. euro (11890 mil. lei). (ZF, 2018)

vii In the world of business corporations and conglomerates, the term Unicorn refers to those startup companies that have a total valuation of more than a billion dollars. The $\$ 1$ billion valuation metric was popularized by the venture investor Aileen Lee, who found that many of the start-ups that reaped the hugest riches for venture capital investors - Facebook and Linkedln, for example - often reached a valuation of $\$ 1$ billion or more while they were privately held. Because of their rarity, Ms. Lee called those companies "unicorns," after the mythical creatures (Benner, 2015). 
Manu, M.V. and Vasile, I.

THE VALUE OF THE NEW BUSINESSES FROM THE DIGITAL ECONOMY: CASE STUDY FROM E-COMMERCE

viii For some reason, the situation of Romania has not been included in this study, showing that there's huge room for such developments.

ix Mosaic was developed by CBInsights (2019) with initial support from the National Science Foundation (NSF)

$\mathrm{X}$ More on this acquisition can be found in the authors' article 'Challenging The Status Quo: Steel Producer Case Study on The Enterprise Value for M\&A', Management Dynamics in the Knowledge Economy, 2019

xi Book Value per Share (B/S) can be calculated by subtracting liabilities from assets, and then dividing it by the total number of currently outstanding shares and it indicates the level of safety for the common shares after removing effects of liabilities to see how much can sell the stake in the company (at liquidation).

xii The Global Unicorn Club, according to (CB Insights, 2018)

xiii Or correlation coefficient 